\title{
As relações entre Arte e Política na Ditadura Militar Brasileira
}

\author{
Luis Claudio Reginato Carvalho' \\ Recebido em setembro de 2020 \\ Aceito em dezembro de 2020
}

\section{RESUMO}

Escrever sobre este assunto é extremamente cativante, já que se trata do Mário Pedrosa que transitou como militante político e grande crítico de arte. Nesse ano de 2020, relembro que se comemora não só os cento e vinte anos de seu nascimento mas também de seus estudos, artigos em jornais, mostras de artes e de lutas e resistência ao establishment brasileiro, cuja sociedade persistiu desde sempre em não tolerar que as mesmas chances e oportunidades de trabalho, cultura, entre outros direitos do cidadão fossem dadas para a camada mais popular da população em todo o país. Contudo, este artigo irá percorrer um caminho complexo daquele momento, vivido por Mário Pedrosa na década de sessenta, e da indissociabilidade da arte com a política, precisamente representada nesse contexto.

Palavras-chave: arte; desenvolvimentismo; marxismo; análise econômica; transição; ditadura militar; instituições nacionais; política; partilha; sociedade.

Iniciando a pesquisa e fundamentação para esse artigo já tinha em mente o tamanho do grande desafio e responsabilidade que seria elaborar este trabalho sob o mote tão importante dos cento e vinte anos de Mário Pedrosa.

A elaboração deste artigo vai desde o nascimento de Mário Pedrosa, a Partilha do Sensível de Jacques Rancière, contextualizando as relações entre arte e política com a historiografia da ditadura militar brasileira até as instituições de cunho cultural e social que fizeram parte de toda a vida de Mário Pedrosa.

Escrever sobre este assunto é extremamente cativante, já que se trata do Mário Pedrosa que transitou como militante político e grande crítico de arte. Nesse ano de 2020, relembro que se comemora não só os cento e vinte anos de seu nascimento mas também de seus estudos, artigos em jornais, mostras de artes e de lutas e resistência ao establishment $^{2}$ brasileiro, cuja sociedade persistiu desde sempre em não tolerar que as

\footnotetext{
${ }^{1}$ Graduado em História, no Departamento de História e Licenciatura na Faculdade de Educação, ambos na Universidade de São Paulo - USP. Mestrando em História Econômica no Programa de Pós-Graduação em História Econômica na USP.

${ }^{2}$ Establishment: substantivo masculino - a ordem ideológica, econômica, política e legal que constitui uma sociedade ou um Estado.: "o e. brasileiro"; - a elite social, econômica e política de um país. - "o e. no Brasil sempre apoia os políticos vitoriosos".
} 
mesmas chances e oportunidades de trabalho, cultura, entre outros direitos do cidadão fossem dadas para a camada mais popular da população em todo o país. Contudo, este artigo irá percorrer um caminho complexo daquele momento, vivido por Mário Pedrosa na década de sessenta, e da indissociabilidade da arte com a política, precisamente representada nesse contexto.

Em um momento que a ditadura militar endurecia com os que não concordavam com a nova ordem política no país, Mário Pedrosa, com o intuito de implementar um projeto de uma nova sociedade, que seu autor chamaria de uma revolução sem luta armada, e buscando o entendimento entre os próprios trabalhadores e participação de sindicatos, Mário Pedrosa lançou as obras: “A opção brasileira”, e "A opção imperialista" 4 . O objetivo era que se desenvolvesse uma consciência de classe, inexistente nas camadas mais populares.

Serão unidas nesse estudo a Partilha do Sensível de Rancière com Mário Pedrosa. Mas não o Mário Pedrosa escritor, crítico de artes, jornalista, tradutor, mas como se fosse possível fazer um abarcamento em um só ser humano, e unir ao primeiro, o grande pensador da política no Brasil.

É realmente um grande desafio unir em um mesmo tema este projeto à história econômica, em um momento que precisa retornar ao seu lugar de destaque na Academia.

Inicialmente será estudado quem era ele, o que fazia, porque fazia, e como fazia, desde sua juventude até o momento que viveu pela segunda vez um Estado de exceção (1937, 1964) em sua pátria.

Sua biografia, já muito bem investigadas por pesquisadores, como, José Castilho Marques Neto, Isabel Loureiro, Dainis Karepovs, Francisco Alambert, Otília Arantes e Everaldo de Oliveira Andrade, se resume inicialmente ao nascimento em Timbaúba, Pernambuco, no ano de 190o. Filho de burocrata, ligado aos negócios do Estado, o jovem vai estudar em um internato na Suíça. Já vivendo no Rio de Janeiro, e de volta ao Brasil, por causa da primeira guerra mundial, conclui o curso de direito. A partir desse momento, passa a se interessar pelo marxismo e a se preocupar com questões sociais.

\footnotetext{
3 PEDROSA, M. A opção brasileira. Rio de Janeiro: Civilização Brasileira, 1966.

4 PEDROSA, M. A opção imperialista. Rio de Janeiro: Civilização Brasileira, 1966.
} 
Em 1926, entra no Partido Comunista Brasileiro (PCB), ganha o prêmio para estudar na Escola Leninista de Moscou. Entretanto, não chegou a estudar lá, primeiro por motivo de saúde, e depois por entender que o momento que atravessava a União Soviética não seria propício a ele. Com a morte de Lenin em 1924, Stálin chegava ao poder e sua condução para com a nação não era compreendida por Mário Pedrosa. Neste momento ele se aproxima do pensamento trotskista, e de Leon Trotsky, da internacionalização do socialismo nos demais países, e assim dissemina as ideias da teoria da Revolução Permanente que é diferente e contrária ao socialismo em um país só, modelo defendido por Stalin. Instala-se em Berlim, Alemanha, e fica por um tempo estudando filosofia, estética e economia.

De volta ao Brasil no final da década de vinte, após as turbulências ocorridas na União Soviética, e do fortalecimento político em alguns países pelo fascismo e o nazismo na Europa, passa a integrar grupo trotskista que combatia o Estado Operário Degenerado. Segundo a definição de Trotsky, era a burocracia stalinista que toma o protagonismo do Estado Operário, e do Partido Bolchevique5, criando uma categoria para este setor social, e não uma nova classe social. Por isso era chamado pelos trotskistas de estado operário degenerado, e assim criou divergência política irremediável com Partido Comunista Brasileiro (PCB), apoiador e vinculado à Teoria Stalinista.

Chega à cidade de São Paulo, e funda a Editora Unitas com alguns conhecidos, com o intuito de publicar textos referentes ao marxismo. Em 1933, mesmo sendo advogado, faz a opção pelo jornalismo; por conhecer o que ocorria naquele momento na Alemanha e Itália, participa e ajuda a fundar um jornal de massas, conhecido por "O Homem Livre”. Foram quase dois anos de vida desse veículo de comunicação, voltado

\footnotetext{
5 Bolchevique: origina-se na doutrina da ala esquerda majoritária do Partido Operário Social-Democrata Russo, adepta do marxismo revolucionário pregado por Lênin, que tinha como compromissos para os componentes do partido a militância e o engajamento político, implementação integral do programa socialista, liderança proletária e centralizada.
} 
exclusivamente para combater a barbárie, e o avanço do fascismo 6 e do nazismo ${ }^{7}$, que eram regimes que ele como bom marxista conhecia e combateu, e que iniciaram perseguições desde 1933 aos partidos socialistas e comunistas na Europa.

Nesse jornal, em que ele escrevia artigos e notícias, procura a mobilização das camadas de todos os trabalhadores, denunciando esses regimes para o público brasileiro. Mário escreveu artigos que se opunham frontalmente ao fascismo. Contudo, inicia a fase de crítica a obra de artes, do trabalho da gravurista alemã Khäte Kollwitz. Ele continuou ainda na mesma época a escrever e trabalhar com livros, e na linha no editorial de cultura, conforme relato no artigo do professor Everaldo de Oliveira Andrade, de História Contemporânea na FFLCH/USP:

Mário Pedrosa escreveu artigos principalmente sobre temáticas da luta anti-
fascista. Mas também colaborou com temas culturais como uma interessante
resenha sobre o filme recém-lançado Scarface em que ele aproveita para
comparar a prática dos gangsteres de Chicago com àquelas das burguesias de
todos o mundo; uma resenha do livro História do Brasil do poeta Murilo
Mendes em que ele destaca a importância dos poemas sobre Canudos, Palmares
e a revolta da Chibata; e uma longa resenha publicada ao longo de quatro
números sobre a exposição em São Paulo de pinturas da artista alemã Khäte
Kollwitz e que é praticamente sua estreia como futuro e brilhante crítico de
arte. $^{8}$

Conhecedor das práticas de combate utilizadas pelos fascistas, Mário Pedrosa, como homem de lutas, e assim, pode-se dizer que não era somente um burocrata como militante, estando atrás de uma mesa com máquina de escrever, mas participando de atividade de rua, organizando ações antifascistas, e ainda tentando alertar a população brasileira para não fazer como a U.R.S.S. 9 (que desprezou a capacidade do movimento operário) que prefere trilhar o caminho de concessões e acordos com os países

\footnotetext{
${ }^{6}$ Fascismo: substantivo; masculino, movimento político e filosófico ou regime (como o estabelecido por Benito Mussolini na Itália, em 1922), que faz prevalecer os conceitos de nação e raça sobre os valores individuais e que é representado por um governo autocrático, centralizado na figura de um ditador.

${ }^{7}$ Nazismo: substantivo masculino; doutrina e partido do movimento nacional-socialista alemão fundado e liderado por Adolph Hitler 1889-1945; hitlerismo, nacional-socialismo. Perseguia minorias políticas, religiosas (6 milhões de judeus mortos), estimulava a apologia ao novo reich e a raça ariana.

8 ANDRADE, E. O. Mário Pedrosa, antifascista. 2020 jun 12. Disponível em: $<$ https://aterraeredonda.com.br/Mário-pedrosaantifascista/?fbclid=IwAR3JfaBDgTfXhfRGdirqjRZ7sw9B9Z_-cJdoyfJW691hfSzaYwbQO_liRew>. Acesso em: 29 ago. 2020.

9 U.R.S.S.: abreviação para União das Repúblicas Socialistas Soviéticas (1917- 1991).
} 
capitalistas. Mário escreveu em artigo no jornal “O homem livre” nํ17 de 1933:

\begin{abstract}
presos à miragem do socialismo nacional, os dirigentes soviéticos, sem fé nas forças do proletariado internacional, preferiram recorrer aos métodos das negociações diplomáticas, das combinações com os governos capitalistas, das ilusões do pacifismo, à procura de garantia de paz e de segurança pelos acordos e tratados internacionais, os pactos de não-agressão e de amizade, os conchavos "desarmamentistas", e enredar-se na malha das Intrigas diplomáticas imperialistas". E prossegue: "A sorte do Estado soviético sempre esteve indissoluvelmente ligada à sorte das massas oprimidas pelos imperialistas. A política da diplomacia soviética separou porém, os seus interesses imediatos dos interesses das massas proletárias no exterior. (...). É hora do proletariado reafirmar o seu internacionalismo ativo para impor ao mundo capitalista a sua solução, isto é, a civilização radiosa que traz no seu seio. Aos povos europeus às vésperas de serem novamente assassinados, é preciso que a voz poderosa do internacionalismo proletário se faça ouvir.
\end{abstract}

Fato importante foi a fundação em 1936, do Partido Operário Leninista, em que pela primeira vez se vê obrigado ao exílio, com a cassação de seus direitos políticos, pela decretação do Estado Novo em 1937, e da total inexistência de um estado democrático de direito no país.

Exilado em Paris, no ano de 1938, funda e torna-se membro de seu comitê executivo da IV Internacional, em companhia de Leon Trotsky e do fundador do surrealismo André Breton, que elabora o Manifesto por uma Arte Revolucionária Independente e defende que a arte tem um potencial libertário e revolucionário entre si. Conceito, que teve na época, a intenção de levar a classe trabalhadora internacional ao poder político, e os seguidores de Trotsky, chamados de trotskistas a fundar sua própria Internacional Comunista. Deixou a IV Internacional (trotskista), após divergir e não concordar com a posição de Trotsky de apoio a União Soviética (Mário que considera contraditório esse apoio ao pensamento de Estado Operário Degenerado ${ }^{10}$ ), na Segunda Guerra Mundial.

Retornou ao Brasil, clandestinamente em 1941, sendo preso novamente. Solto,

\footnotetext{
${ }^{10}$ Estado Operário degenerado: Leon Trotsky, desenvolve o termo em A Revolução Traída - Global Editora, Brasil, 1980; que para ele, o Estado Operário e o Partido Bolchevique haviam sido "tomados" pela burocracia stalinista, que era um setor que tinha origem no proletariado, mas que, por seus privilégios com os próprios interesses, e era inimigo ao conjunto da classe trabalhadora, tornando-se autônomo em relação à mesma. Para Trotsky, este setor social gerou uma "casta" uma vez que sem ser uma nova classe social por não ter um papel qualitativamente distinto do proletariado no processo de produção, usurpoulhe o poder político.
} 
tem a obrigação de deixar o país, o que faz indo para os Estados Unidos e trabalhando na União Pan-Americana. Em 1942, publica artigo referente aos painéis de Cândido Portinari ${ }^{11}$, instalados na Biblioteca do Congresso dos Estados Unidos, em Washington. A partir de 1943 trabalha em Nova York na seção de cinema do Escritório de Coordenação de Negócios Interamericanos, sendo também correspondente do jornal Correio da Manhã de 1943 a 1945.

Com o fim do governo de Getúlio Vargas em 1945, volta ao Brasil, participa do início da União Socialista Popular e também da criação do semanário A Vanguarda Socialista.

À época entre 1949 e 1951, torna-se professor da antiga Universidade do Brasil (UB), atual Universidade Federal do Rio de Janeiro (UFRJ), na cátedra de História da Arte no departamento de Arquitetura, que influenciou muitos artistas em começo de carreira por seu trabalho em arte com Gestalt, e que no século XX, nas décadas de 50 e 6o, Mário estimulou grandes nomes da arte concreta e do neoconcretismo. Ainda teve tempo para criar no Correio da Manhã em 1949, a seção de artes plásticas. Foi também responsável pela criação do primeiro grupo de vanguarda denominados, artistas concretos no Rio de Janeiro, com Ivan Serpa, Abraham Palattinik, e também dos neoconcretistas, Lígia Clark, Hélio Oitica, Lygia Pape, e Ferreira Gullar. Segundo a professora Otília Beatriz Fiori Arantes, que afirma em seu livro sobre os aristas, que “considera Mário Pedrosa que a tendência expressiva que se encontrará nestes artistas, à exemplo da pintura do artista plástico russo Kandinsky, é a origem de toda a arte, e que a união da sensibilidade com a inteligência teria produzido as obras de arte "mais vivas" da modernidade". ${ }^{2}$

Organizador do programa artístico da II Bienal de São Paulo em 1953, e secretário-geral da IV Bienal Internacional de São Paulo no ano de 1957, Mário estava acostumado a andar em todas as esferas, manteve relação profissional com o empresário que era considerado por muitos como mecenas e incentivador das artes plásticas,

\footnotetext{
${ }^{11}$ Cândido Portinari: nascido em Brodowski, em 1903, pintou mais de cinco mil obras, de pequenos esboços e pinturas de proporções padrão, como O Lavrador de Café, até enormes murais, como os painéis, Guerra e Paz, presenteados à sede da ONU em Nova Iorque em 1956. Considerado pela crítica internacional, como um dos mais importantes pintores brasileiros de todos os tempos, sendo o pintor brasileiro a alcançar maior projeção internacional.

${ }^{12}$ ARANTES, O. B. F. Mário Pedrosa: itinerário crítico. São Paulo. Cosac. Naify, 2004.
} 
Francisco Matarazzo Sobrinho, mais conhecido como Ciccillo Matarazzo.

Mário Pedrosa também foi membro várias vezes do júri de inúmeras bienais de artes plásticas ao redor do mundo e em 1959, organizou o Congresso Internacional em Brasília (cidade projetada por Oscar Niemayer e ainda em construção), São Paulo e Rio de Janeiro. Como crítico de arte manteve o cargo de vice-presidente da Associação Internacional de Críticos de Artes (AICA),1957-1970. Na década de 6o escreve sobre arte e política por anos no Correio da Manhã. Foi diretor da Bienal em 1961 e também diretor do Museu de Arte Moderna de São Paulo (MAN) de 1961 a 1963. Nesse momento foi secretário no Conselho Federal de Cultura do governo Jânio Quadros no ano de 1961 a 1963.

Sobre a política econômica nos anos 6o, tem divergências com os desenvolvimentistas. Dentre eles, o ministro do planejamento do governo JK Celso Furtado a quem cita como criador do Plano Trienal. Este plano cedeu ante a dos capitais estrangeiros na política cambial, durante o tempo que resistiu à pressão da finança internacional no que concerne a sustentação dos investimentos do setor estatal conforme Mário Pedrosa escreve na página 3 de seu artigo ‘Entreguismo e nacionalismo”, do Jornal do Brasil em 102 de agosto de 1959. Mário acreditou que o desenvolvimentismo brasileiro cresceu e se formou através da barganha do Imperialismo. Criticou também os comunistas ligados ao Partido Comunista Brasileiro (PCB), em que, "rejeita a tese dominante na esquerda, de que seria possível uma revolução burguesa no Brasil, com desenvolvimento social, pois nossas elites estavam submissas sob as ordens do capital financeiro internacional, que segundo Pedrosa ditava as regras de uma política econômica de mercado e neoliberal, a qual seria obediente conforme afirmei anteriormente aos interesses do capital internacional.”. ${ }^{3}$

Com o Golpe de 1964, Mário Pedrosa nos traz seu diagnóstico do Regime Militar de 1964 em comparação com o governo Vargas além de concluir o capítulo quatro do livro “A Opção Brasileira” de 1966 onde contava que o golpe e o regime militar de 64 estavam ligados ao capitalismo internacional imperialista, momento pelo qual as Forças Armadas Brasileiras estavam sob forte influência do Estado Americano, de suas

\footnotetext{
${ }^{13}$ DI CARLO, J. O desenvolvimentismo na crítica de Mário Pedrosa. MovimentAção, v. 5, n. 8, p. 18-37, 2018.
} 
corporações, de empresas e financeiras, em que podia-se considerar as forças armadas até como uma analogia de "um adido militar da embaixada estadunidense no Brasil", e este prejudicando setores da própria burguesia nacional, diferente da mentalidade na época do presidente Getúlio Vargas. Naquele momento houve a criação das várias companhias estatais, como a Companhia Siderúrgica Nacional (CSN), Companhia Vale do Rio Doce, Hidrelétrica do Vale do São Francisco, a Fábrica Nacional de Motores (FNM), e a campanha do "petróleo é nosso", pela empresa criada em 1953 com o nome de Petrobras, com a grande descoberta das jazidas de petróleo em 1954 na Bahia. Com o intuito de se fortalecer o investimento financeiro externo americano (que foi negociado com Vargas), o parque industrial se desenvolve rapidamente nessa época com o apoio do Estado e através da política desenvolvimentista, que deu prosseguimento com o mandato do presidente Juscelino Kubitschek (1956-1961).

Todavia, na visão que Mário tinha como militante político ele observou que seria impossível termos objetivos alcançados com esse modelo (desenvolvimentista), já que não havia uma burguesia industrial progressista favorável às instituições democráticas, que, ao mesmo tempo, não sendo a favor do desenvolvimento social e financeiro da camada trabalhadora urbana e do campo. O que o leva a teorizar por uma revolução apoiada pelas massas e organizada pelos sindicatos como representantes da classe trabalhadora, mas sem a luta armada. Mário acredita num movimento de passagem para o socialismo nos países do terceiro mundo, com o pensamento que uniria o gerenciamento de negócios das grandes corporações estadunidenses com o modelo de empresas estatais soviéticas. Complexo, mas muito marxista, já que em sua ideia se concentrava a tese original de Karl Marx, em que a revolução comunista estava ligada com o máximo desenvolvimento das contradições do capitalismo, como último passo para o socialismo.

Em resumo, ele foi um homem do Século XX, mas que compreendia na heterodoxia do pensar, a arte e a política, se unindo na complexidade para caminharem juntas e sempre, passando subjetivamente a sensação de estarem juntas, e assim dando uma percepção física para abranger que os conceitos de arte e revolução social caminham juntos, um verdadeiro marxista.

Em outra chave que complementa, ou melhor, estabelece uma conexão com esse 
artigo, se encontra a História Econômica, ela que no seu entender é de grande importância para a sociedade, entra em cena depois de analisarmos melhor a questão da arte e a política.

Por quê? Porque em muitos momentos de sua vida, Mário Pedrosa trabalha com artigos de crítica de arte, mostras culturais, aulas, e traduções, mas jamais sem esquecer do pensamento político e que a economia reflete como parte dessa sua preocupação com conquistas para a sociedade pelo homem novo.

Chega a ser muito precisa e correta como o pensar de dois estudiosos de Mário Pedrosa, como o de Marcelo Ribeiro Vasconcelos e Marcelo Mari, sendo que o primeiro em sua tese de doutorado em Filosofia pela UNICAMP: "O exílio de Mário Pedrosa nos Estados Unidos e os New York Intellectuals: abstracionismo na barbárie”, e o segundo autor que pesquisou também em sua tese de doutorado em Filosofia e Ciências Humanas pela USP, com o tema: "Estética e política em Mário Pedrosa (1930-1950)". Analises que vão a fundo no conceito que Pedrosa vislumbra através da força que a arte tem, construindo um modelo de uma nova sociedade mais igualitária.

Como também se pode encontrar na relação à "arte política" em que existe a provocação elaborada pelo filósofo francês Jacques Rancière, que caminhou pelo universo da arte e com análise peculiar conseguiu observar o que artistas pretenderam fazer com que suas obras não ficassem somente na esfera artística e sim produzissem efeitos práticos no mundo real.

Um caminho relatado aqui anteriormente, em que esse caminho também é percorrido ideologicamente por Mário Pedrosa. Exemplos não faltam, o grupo de artistas concretistas que ele reúne e exerce encontros com debates sobre essa dinâmica. Nomes como Ferreira Gullar, Hélio Oiticica, Lygia Clark, entre tantos outros, que se rebelam e criam o neoconcretismo como adversidade revolucionária ao concretismo e sua tendência racional, positivista, dogmática e técnico-científica.

Movimentação compreendida pelo contexto, pela época, e também espaço, trazendo algo extremamente significativo, e mostrando-se revolucionário, pois nesse momento a arte estava sendo disputado em pleno litígio e enfrentamento do pensamento neoliberal, em oposição ao desenvolvimentismo e os pensamentos de uma arte popular pelas elites subservientes ao capital estrangeiro. 
O Brasil na década de 60 se encontra numa disputa política, grupos conservadores nos costumes e ultraliberais no pensamento econômico organizam o golpe, para a implantação ditatorial, que foi bancada pela elite subserviente, e ligada ao corporativismo Imperialista em uma periferia mundial.

Os movimentos populares, os sindicatos e artistas necessitam se organizar como movimentos que pretendem resistir e desafrouxar as amarras do subdesenvolvimentismo colocadas pelos Nações ligadas a ideologia do Imperialismo estadunidense.

O projeto vai se organizando e chega na década de setenta com uma proposta de decolonialismo, quer ultrapassar a essa face obscura de modernidade, e que permanece operando ainda nos dias de hoje em um padrão mundial de poder da ideologia colonial e eurocentrista. Porque conforme me relatou Marcia Basseto Paes,

[...] para Mário Pedrosa interessava a forma como a burguesia se apropriava da arte como mercadoria e, portanto, a descaracterizava para simplesmente cumprir função no processo de acumulação de capital. Para Mário a burguesia, o liberalismo burguês, aceita todas as obras de bate-pronto. A vilipendia, polui, apodrece, digere e cospe para o consumo. Em 1978 Mário dizia que como a burguesia não tem mais força para impor valores que são dela, ela aceita qualquer coisa porque pode ser que algum dia aquilo pode proporcionar lucro.

Segundo ainda Marcia Basseto Paes, que por anos trabalhou e o ajudando a organizar seus livros, arquivos e peças de arte nessa época para Mário Pedrosa, e com que tive a oportunidade de trocar alguns e-mails sobre o assunto, ela relatou que a grande percepção a que Mário pode nos trazer, foi de um processo através da concepção da proposta de criação do Museu das Origens foi publicada no Jornal do Brasil do dia seguinte e em Arte Hoje de outubro de 1978. O Museu das Origens se comporia de cinco museus - do Índio; de Arte Virgem, Museu do Inconsciente; do Negro; de Arte Moderna e de Artes Populares. O novo Museu de Arte Moderna deveria reconstituir um acervo “representativo da arte brasileira”, no entender de Mário.

Essa busca pela superação à dominação ideológica das Nações Imperialistas para com outras que já tinham identidade cultural própria, já se vê desde muito cedo, nos anos de 1930, segundo nos informa Marcelo Ribeiro Vasconcelos em sua tese de doutorado, conforme cito abaixo: 
A tese tem como principal objetivo a análise sobre as experiências de exílio de Mário Pedrosa nos Estados Unidos (1938-1945) e os impactos de tais experiências em suas práticas e posições. Foi privilegiada ao longo da análise a observação das formas de sua participação em um campo de disputas estabelecido pela imprensa radical nova-iorquina, que tinha como principal elemento em disputa as formas e o sentido do radicalismo cultural. Nos EUA, desde as primeiras décadas do século XX, radicalismo político e modernismo cultural acabam por se entrelaçar como uma possibilidade de superação da tradição anglo-saxã.

Vê-se que esse processo de Decolonialismo para Nações periféricas e principalmente para o Brasil, se torna claro em suas projeções, pois Mário, já naquela época lançava a hipótese de libertação cultural, social e também econômica, e como trotskista, acreditou que ela ocorreria através de uma libertação proletária e popular para com aquela elite nacional submissa ao Imperialismo mundial.

Marcelo Mari que também em sua tese de doutorado analisa a crítica de Mário Pedrosa, em que estuda e analisa a contribuição pedrosiana de modo decisivo na formação e no desenvolvimento do meio político e artístico brasileiro. Aqui mais especificamente a influência sobre a obra da artista gravurista alemã Käthe Kollwitz, que em 1933, Pedrosa pronunciou em conferência sobre ela e "defendeu uma arte tendenciosa que tomasse partido em favor da luta revolucionária e internacionalista do proletariado". Mari alerta para o que se define como uma:

[...] pressão dos acontecimentos políticos e sociais e que se fez sentir de tal forma no ambiente artístico e cultural do Brasil que artistas, escritores e intelectuais começaram a participar mais ativamente da política" (...). "A política passava a ter maior relevância do que a discussão centrada sobre a legitimidade ou não da arte moderna ou, como diria Mário Pedrosa, as polêmicas deixavam de ser artísticas para se tornarem políticas.

No caso da pesquisa que faço sobre o pensador Mário Pedrosa, deve-se esclarecer que aprofundo no ponto de vista econômico, e como ele pode agir conectado e sem ruptura de esclarecer o assunto que o projeto trata. Um homem que é crítico de arte por opção, e jornalista por profissão, que pretende trazer um novo pensamento político-econômico para um país periférico e subdesenvolvido, vivendo o Estado de Exceção, com uma política econômica remanescente de seus últimos anos no 
desenvolvimentismo, e que inicia uma nova e amarga fase neoliberal, que a longo prazo arrastará o país para uma crise inflacionária e de uma dívida externa colossal. E como Marx disse, "o capitalismo necessita das crises cíclicas nas políticas econômica, e social para sobreviver, sendo provocadas pelas próprias leis do funcionamento capitalista no sistema econômico liberal.”.

A influência trotskista também é proeminente, o internacionalismo é a grande marca para essa arte, já que não se aceita o regionalismo defendido pelos partidos comunistas. Cito Marcelo Mari, que a mensagem e a intervenção da arte para Mário Pedrosa estavam na área de: "como lutar por um tipo de internacionalismo nas artes que fizesse frente à divisão internacional do trabalho resultante da perpetuação das relações desiguais e combinadas entre centro e periferia no Capitalismo.”.

Mário sempre teve essa antevisão com o assunto, e mesmo que ele não seja um economista de formação, e projetando algo de fora da "bolha do economês", através de sua 'práxis', com os estudos marxistas, e experiências em outros países, ele teve a oportunidade de conhecer, e comutar informações com inúmeros estudiosos do assunto em questão, para alcançar um objetivo, e que fosse de um início através de um país socialista, voltado mais para as questões humanas e menos para as questões do mercado, em um sistema capitalista mundial.

Nesse caso se torna importante que o respaldo do estudo e da pesquisa necessite não só do meu entendimento, mas também do conhecimento de outros historiadores que conseguiram de forma correta e segura apresentar os fatos da História Econômica.

No artigo "História econômica: algumas questões metodológicas" da professora Luciana Lamblet Pereira de História Contemporânea da Universidade Federal Fluminense (UFF), para o XXII Simpósio Nacional de História, em Londrina, em 2005.

Concordo que para uma pesquisa unificadora com duas disciplinas, sendo a Economia e a História, para se compreender a História Econômica, é preciso entender como se relacionam e conversam entre si. Assim desde o Século XIX, existe o conflito de ideias entre a Escola Histórica, que é uma corrente que reforça os aspectos individuais do desenvolvimento econômico, defendendo as especificidades do mesmo em vários países, que difere das ideias de Smith e Ricardo, que eram concepções mais generalizantes. 
Com o surgimento e o crescimento da classe operária nesse mesmo século é estimulado o interesse sobre a história econômica, que tem, nessa mesma época, uma grande influência pela teoria marxista.

Luciana L. Pereira, afirma ainda em seu artigo:

[...] que o historiador econômico não caia no tão repudiado anacronismo, aplicando variáveis concernentes à empresa capitalista, compreendo a necessidade de estudar as relações internas do sistema econômico da sociedade abordada com sua estrutura social, evitando, com isso, o risco das generalizações, geralmente cometidas pela economia retrospectiva. ${ }^{14}$

No artigo a autora entende que na obra "Sobre História"15, do historiador marxista Eric Hobsbawm, os economistas tinham o hábito de apartar a história em seus trabalhos, e não dando ênfase às mudanças do conjunto em toda sociedade. No livro o autor deixa claro que a economia não pode ser separada, pois, faz parte da essência da história, senão terá perdido sensivelmente o seu realismo enquanto ciência social aplicada.

Acredita que não se pode fechar em pequenos compartimentos separados, como História do Poder e Ideias Políticas e História Cultural, o que sem dúvida está correta, e assim haverá uma história em sua totalidade, pois se sabe que na sociedade não existe somente o homus econômico, ou político, e um outro cultural.

Para Hobsbawm, o ser humano vive em sua totalidade, com seus conflitos pessoais, suas vidas particulares e suas hesitações, e que em suas relações e o jeito de se ver nesse mundo novo, ele tem para dar sua contribuição à História Econômica.

Nesse momento penso que a utilização da História Econômica como uma das vigas que pretendo dar alicerce para produzir nesse artigo, olhando sem preconceito para as críticas, para a produção de debates anteriores, e que leve à produção de minha pesquisa, em que há um Mário Pedrosa crítico de arte, constituindo parte importante na partilha do sensível, e um “outro” Mário Pedrosa, pensador político com viés ao estudo político econômico para solução do problema social de uma nação periférica a partir de

\footnotetext{
${ }^{14}$ PEREIRA, L. L. História econômica: algumas questões metodológicas. ANPUH - XXIII Simpósio Nacional de História, 2005. Disponível em: <https://anpuh.org.br/uploads/anais-simposios/pdf/201901/1548206369_3be6aoaobbcc555958194da64a18d92c.pdf>. Acesso em: 29 ago. 2020.

${ }^{15}$ HOBSBAWM, E. J. Sobre história. São Paulo: Companhia das Letras, 1998.
} 
minhas fontes.

Essa análise passa a partir da obra de Rancère, de como foram as relações entre a arte e a política em uma época de um passado recente - o golpe de 64, e que tanto foi importante para a cultura nas relações que as instituições nacionais (ABI, CNBB, OAB, entre outras) se mobilizaram por proteção ao Estado de Direito da população desprotegida.

A Ditadura Militar Brasileira teve o enfrentamento e resistência de alguns setores da sociedade com o golpe civil / militar de 1964 e, mesmo que tivesse inicialmente o apoio dessa sociedade, o que ocorreu foi que muitos grupos se estruturaram para combater o que era a perda do estado democrático de direito. Esse processo de um "contragolpe" de alguns setores da sociedade, como por exemplo, sindicatos de trabalhadores, estudantes, artistas, professores, começa em primeiro de abril de 1964 e sobrevive, atinge e ultrapassa com muita luta, o treze de dezembro do ano de 1968 com o Ato Institucional nº 5 decretado pelo governo autocrata.

Os setores ligados a arte, cultura, educação, que eram a princípio, os artistas, escritores, estudantes, não contava com a simpatia e apoio de algumas instituições (citadas a dois parágrafo acima) que se tornaram no final da década de 70 em pilares da redemocratização com a mudança de comportamento e da opinião da sociedade brasileira já no fim da ditadura, que já se prenunciava seu final para o começo da década de 8 o.

Instituições ${ }^{16}$ como a Associação Brasileira de Imprensa (ABI), Ordem dos Advogados do Brasil (OAB), e Confederação Nacional de Bispos do Brasil (CNBB), que somente com o processo, e do andamento de medidas autocráticas do golpe, foram percebendo com o tempo, e a luz, o que realmente tinham em mente os militares. Em parceria com alguns setores da elite empresarial, pois no início, essas instituições sociais e políticas até deram apoio ou silenciaram ao que para eles seriam como uma salvação do comunismo que, assim diziam, que o movimento popular de esquerda estava

\footnotetext{
${ }^{16}$ ROLLEMBERG, D. As trincheiras da memória. A Associação Brasileira de Imprensa e a ditadura (19641974). In: ROLLEMBERG, D.; QUADRAT, S. V. (Org.). A construção social dos regimes autoritários: legitimidade, consenso e consentimento no Século XX. Rio de Janeiro: Civilização Brasileira, 2010. v. 2: Brasil e América Latina; ROLLEMBERG, D. Memória, opinião e cultura política. A Ordem dos Advogados do Brasil sob a Ditadura (1964-1974). In: REIS, D. A.; ROLLAND, D. (Orgs.). Modernidades alternativas. Rio de Janeiro: Fundação Getúlio Vargas, 2008, p. 57-96.
} 
instalando no país o caos urbano e rural.

Conforme artigo de Marcelo Ridenti, ${ }^{17}$ temos o estudo do sociólogo Sergio MIceli, que, "a maioria dos intelectuais desse período [1920-45] pertencia à família de 'parentes pobres' da oligarquia ou, então, a famílias de longa data especializadas no desempenho dos encargos políticos e culturais de maior prestígio". ${ }^{18}$ Eram oriundos das famílias tradicionais do nordeste brasileiro e do Rio de Janeiro, e tendo sido deslocados de sua posição social, o que com isso podiam enxergar a realidade de outros pontos de vista sociais, segundo Leôncio Martins Rodrigues, os principais dirigentes comunistas. Sendo que o dirigente esquerdista típico seria "o jovem intelectualizado de família tradicional decadente dos Estados pobres" ${ }^{19}$

Segundo os pesquisadores Miceli e Rodrigues, a análise feita para a primeira metade do Século XX pode ser para o período posterior, pois vários militantes, intelectuais, e artistas, continuaram com sua atuação na segunda metade e na década de 6o ainda seriam até mais importantes, pois existem dados quantitativos, quanto qualitativos, dos grupos compostos por artistas, políticos, intelectuais. Eram as novas classes médias que se tomavam espaço na sociedade.

Concordante às páginas anteriores, observo um Mário Pedrosa crítico de arte totalmente envolvido e inserido na Partilha do Sensível a que Rancière nos ensina, sendo o intelectual ligado às artes de forma crítica e consciente, pois para ele, o aprender é uma forma de libertação para todos os envolvidos, e não só para poucos privilegiados.

Lendo a biografia de Mário Pedrosa, escrita nas primeiras páginas desse artigo, vem incrivelmente de encontro com tudo o que Marcelo Ridenti, Sergio Miceli, e Leoncio M. Rodrigues descrevem sobre as características e predicados dos intelectuais e pessoas ligadas as artes e cultura, na política.

O termo partilha foi estudado em curso que tive a oportunidade de participar e que foi ministrado pela professora de história Míriam Hermeto da UFMG. Ela me despertou, e me levou a pensar que a palavra partilha tem dois sentidos, e é com esses

\footnotetext{
${ }^{17}$ RIDENTI, M. Intelectuais e artistas brasileiros - nos anos 1960/70: "entre a pena e o fuzil". ArtCultura, v. 9, n. 14, p.185-195, jan./jun. 2007.

${ }^{18}$ MICELI, S. Intelectuais à brasileira. São Paulo: Companhia das Letras, 2001.

${ }^{19}$ RODRIGUES, L. M. O PCB: os dirigentes e a organização. In: FAUSTO, B (org.). História geral da civilização brasileira. São Paulo: Difel, 1981.
} 
dois sentidos que se fazem compreender em primeiro lugar a aquilo a que me pertence, e é depois também, aquilo em que eu compartilho. Assim se encontra com o Mário Pedrosa um intelectual, mas engajado politicamente que por acreditar que a revolução em partilha com a arte será benéfica para a nação.

No livro "A Opção Brasileira"2o em seu capítulo quatro, ele aponta que a opção é mesmo de revolução já que primeiro o presidente João Goulart trai todas as expectativas e não consegue governar, assim se instalando o caos. E também as elites que até esse momento jamais conseguiram a sobrevivência sem a ajuda do Estado, e que sua única preocupação é a subserviência ao Imperialismo estadunidense. Entretanto, esse sistema econômico criado pelo governo ditatorial brasileiro de cunho neoliberal, será depois de alguns anos muito criticado pelos empresários "tupiniquins".

Pedrosa não comete deslize na sua análise, e sabe que um novo Imperialismo dirigido pelo Estado, ainda existindo com o velho imperialismo, que nada mais era que a união do capital estatal que financia projetos do setor estrutural e o capital privado e estrangeiro que financia setores da indústria, dando suporte para alavancar os Estados Unidos da América como a superpotência imperialista no século passado "Foi a época do apogeu do desenvolvimentismo, marca JK". ${ }^{21}$

O comum também se encontra nele, e não é só na estética, mas também na política, pois Mário Pedrosa pretende a popularização cada vez maior, mesmo depois de ser considerado o maior crítico brasileiro de artes plásticas, e oriundo de família oligárquica nordestina em decadência, como nos lembra Marcelo Ridenti.

Mário Pedrosa enfim busca dentro desse contexto que a transformação aconteça com a consciência de classe da população trabalhadora, e sendo que o fruto do trabalho deve continuar através das conquistas sociais, com uma evolução econômica, intelectual, e na vida cotidiana, que assim numa dialética, termina coma subserviência de quem não concorda com o que é o parasita nessa engrenagem da meritocracia capitalista. Assim o homem novo surgirá e terá a possibilidade de alcançar a libertação, com ajuda e parceria do Estado, Conselhos e Sindicatos, em uma próxima etapa entre a passagem do capitalismo para o socialismo.

\footnotetext{
${ }^{20}$ PEDROSA, M. A opção brasileira. Rio de Janeiro: Ed. Civilização Brasileira, 1966, p.181- 245.

${ }^{21}$ PEDROSA, M. A opção brasileira. Rio de Janeiro: Ed. Civilização Brasileira, 1966, p. 203.
} 
Com valores partilhados que sejam trazidos do passado, rompendo com o presente, e trazendo perspectivas melhores das que se apresentam nesse presente, e se apropriando do partilhado universalmente e também na temporalidade.

Quebra-se a bipolaridade da repressão e resistência, para encontrar a acomodação como fronteira tênue dessa condição, rompendo o sistema binário, havendo além da simples resistência, uma resistência plural. Essa estava para Mário Pedrosa num mesmo eixo do intelectual preocupado com a arte alcançando e levando ensinamento e cultura a todos, em conjunto, com aquele que nunca esteve separado do primeiro, que como militante político pode acreditar numa nova possibilidade de vida para uma nação periférica, latino-americana, em uma sociedade mais uniforme com menos desigualdade, libertando-se de uma elite que em grande parte ainda vivia de ideias que não eram apenas conservadores, mas arcaicas e ultrapassadas, sufocando aos que realmente movimentam a roda da economia, e que é, seus trabalhadores.

\section{Referências}

ALONSO, G. "O preto que ri” ou um negro entre Zumbis e Tornados. In: Simonal: quem não tem swing morre com a boca cheia de formiga. Rio de Janeiro: Record, 2011. p. 79141.

AMATO, G. Ele compra o "Lampião", mas manda embrulhar: reconfigurações do sensível no documentário “Lampião da esquina” (2016). PPGHIS-UFMG, 2018.

ANDERSON, P. Internacionalismo: um breviário. Anos 9o, Porto Alegre, v. 12, n. 21/22, p. 13-42, jan./dez. 2005.

ANDRADE, E. O. Mário Pedrosa, antifascista. 2020 jun 12. Disponível em: $<$ https://aterraeredonda.com.br/Mário-pedrosaantifascista/?fbclid=IwAR3JfaBDgTfXhfRGdirqjRZ7sw9B9Z_cJdoyfJW691hfSzaYwbQO_liRew>. Acesso em: 29 ago. 2020.

Mário Pedrosa, o golpe de 1964 e a crítica ao desenvolvimentismo. Revista Perseu: História, Memória e Política, p. 263-28o, 2016.

Mário Pedrosa. In: SECCO, L.; PERICÁS, L. (Orgs.). Intérpretes do Brasil, clássicos, rebeldes e renegados. São Paulo; Boitempo, 2014.

O debate sobre a planificação econômica socialista no Brasil. São Paulo: 
Mimeo, 2013.

ARANTES, O. B. F. Mário Pedrosa: itinerário crítico. São Paulo. Cosac. Naify, 2004.

BATISTA, N. O processo de montagem em São Paulo: pode o povo estar na Bienal? In: O tempo em processo: cultura na ditadura militar e os impasses em torno do popular na peça "O Último Carro" (1964-1978). Tese (Doutorado) - PPG História Social, USP, 2019. p. 227-293.

BERTELLI, A. R. (Org.) A Nova Política Econômica (NEP) - Capitalismo de Estado, transição e socialismo. São Paulo: Global Editora, 1987.

BIELSCHOWSKY, R. Pensamento econômico brasileiro. 4. ed. Rio de Janeiro: Contraponto, 2000.

BRANDÃO, T. O teatro brasileiro do século 20. Revista do Patrimônio Histórico e Artístico Nacional. Olhar o Brasil, n. 29, 2001.

CARDENUTO, R. Dramaturgia de avaliação: o teatro político dos anos 1970. Estudos Avançados, v. 26, n. 76, p. 311-332, 2012.

CHAUÍ, M. Cultura e resistência. São Paulo: Brasiliense, 1986.

DI CARLO, J. O desenvolvimentismo na crítica de Mário Pedrosa. MovimentAção, v. 5, n. 8, p. 18-37, 2018.

FICO, C. Ditadura militar brasileira: aproximações teóricas e historiográficas. Revista Tempo e Argumento, v. 9, n. 20, p. 5-8, jan./abr. 2017.

FRANCO, R. Itinerário político do romance pós-64: a festa. São Paulo: EdUnesp, 1998.

GARCIA, M. Do teatro militante à música engajada: a experiência do CPC da UNE (1958-1964). São Paulo: Fundação Perseu Abramo, 2007.

GAUDENCIO, L. A partilha do Cruzeiro: rearranjos de identidades sem-valor. PPGHIS-UFMG, 2018.

HOBSBAWM, E. J. Sobre história. São Paulo: Companhia das Letras, 1998.

KAREPOVS, D. Pas de politique Mariô! Mário Pedrosa e a política. São Paulo: Ateliê Editorial, 2017.

; MARQUES NETO, J. C.; LOWY, M. Trotsky e o Brasil. In: MORAES, J. Q. (Org.). História do marxismo no Brasil. Campinas: Editora Unicamp, 1995. v. II. 
KONDER, L. Marx: vida e obra. 3. ed. São Paulo, Expressão Popular, 2015.

LÖWY, M. A teoria do desenvolvimento desigual e combinado. sd. Disponível em: http://www.afoiceeomartelo.com.br/posfsa/Autores/Lowy,\%2oMichael/a\%2oteoria\%20 do\%2odesenvolvimento\%2odesigual\%20e\%20combinado.pdf. Acesso em: 26 out. 2020.

LUNARDI, R. Elis Regina: entre o canto e a política na década de 1970. ArtCultura (UFU). v. 29, p. 187-202, 2014.

LUXEMBURGO, R. Greve de massas, partido e sindicatos. In: BOGO, A. Teoria da organização política. Escritos de Engels - Marx - Lenin - Rosa - Mao. São Paulo: Expressão Popular, 2005.

MARI, M. Estética e política em Mário Pedrosa (1930-1950). Tese (Doutorado em Filosofia) - Faculdade de Filosofia, Letras e Ciências Humanas, Universidade de São Paulo, São Paulo, 2006.

Mário Pedrosa: Agit prop e arte independente na periferia capitalista. In: Arte e vida social: pesquisas recentes no Brasil e na França. Marseille: OpenEdition Press, 2016.

MARX, K.; ENGELS, F.; COGGIOLA, O. (Org.). O manifesto comunista. São Paulo; Boitempo Editorial. 1998.

MICELI, S. Intelectuais à brasileira. São Paulo: Companhia das Letras, 2001.

NAPOLITANO, M. A arte engajada e seus públicos. In: Estudos históricos. Rio de Janeiro: FGV, 2001.

PACHECO, T. Teatro alternativo em 70: a luz no final do túnel. In: MELLO, M. A. (org.). 20 anos de resistência. Alternativas da Cultura no Regime Militar. Rio de Janeiro: Espaço e Tempo, 1986. p. 95-106.

PATRIOTA, R. O teatro e o historiador: interlocuções entre linguagem artística e pesquisa histórica. In: RAMOS, A. F., PEIXOTO, F.; PATRIOTA, R. (orgs.). A história invade a cena. São Paulo: Aderaldo \& Rothschild, 2008. p. 26-58.

PEDROSA, M. A opção brasileira. Rio de Janeiro: Ed. Civilização Brasileira, 1966. A opção imperialista. Rio de Janeiro: Civilização Brasileira, 1966. . Entreguismo e nacionalismo. Jornal do Brasil, a. LXIX, n. 179, p.3 e 8, 2 ago. 1959. O partido do gabarito curto. Jornal do Brasil, a. LXIX, n. 1, p. 3, 1 jan. 1960.

PEREIRA, L. C. Desenvolvimento e crise no Brasil. São Paulo: Brasiliense, 1979. 
PEREIRA, L. L. História econômica: algumas questões metodológicas. ANPUH - XXIII Simpósio Nacional de História, 2005. Disponível em: <https://anpuh.org.br/uploads/anais-simposios/pdf/2019o1/1548206369_3be6aoaobbcc555958194da64a18d92c.pdf>. Acesso em: 29 ago. 2020.

PERICÁS, L. B. Caio Prado Jr. - uma biografia política. São Paulo, Boitempo, 2016. . Che Guevara e o debate econômico em Cuba. São Paulo: Xamã, 2004.

PRADO JÚNIOR, C. A revolução brasileira. 7. ed. São Paulo: Brasiliense, 1987. . Evolução política do Brasil. São Paulo: Companhia das Letras, 2012.

. Formação do Brasil contemporâneo. São Paulo: Companhia das Letras, 2011.

PREOBRAJENSKY, E. A nova economia. Rio de Janeiro: Paz e Terra, 1979.

RANCIÈRE, J. A noite dos proletários. São Paulo: Companhia das Letras, 1998.

. A partilha do sensível: estética e política. São Paulo, EXO / Ed. 34, 2005.

. O desentendimento. São Paulo: Ed. 34, 1996.

. O espectador emancipado. São Paulo: Martins Fontes, 2012.

. O mestre ignorante. Belo Horizonte: Autêntica, 2002.

. Os nomes da história. Educ/Pontes, 1994.

. Políticas da escrita. São Paulo: Ed. 34, 1995.

RIBEIRO VASCONCELOS, M. O exílio de Mário Pedrosa nos Estados Unidos e os New York Intellectuals: abstracionismo na barbárie. 2018. Tese (Doutorado em Filosofia e Ciências Humanas) - Universidade Estadual de Campinas, Campinas, 2018.

RIBEIRO, I. L. C. Uma leitura de “A noite da espera” (Milton Hatoum, 2017). PPGHIS-UFMG, 2018.

RIDENTI, M. As oposições à ditadura: resistência e integração. In: MOTTA, R. P. S.; REIS FILHO, D. A.; RIDENTI, M. A ditadura que mudou o Brasil: 50 anos do golpe de 1964 . Rio de Janeiro: Zahar, 2014. v. 1. p. 30-47.

. Intelectuais e artistas brasileiros - nos anos 1960/70: "entre a pena e o fuzil". ArtCultura, v. 9, n. 14, p.185-195, jan./jun. 2007.

RODRIGUES, L. M. O PCB: os dirigentes e a organização. In: FAUSTO, B (org.). História 
geral da civilização brasileira. São Paulo: Difel, 1981.

ROLLEMBERG, D. As trincheiras da memória. A Associação Brasileira de Imprensa e a ditadura (1964-1974). In: ROLLEMBERG, D.; QUADRAT, S. V. (Org.). A construção social dos regimes autoritários: legitimidade, consenso e consentimento no Século XX. Rio de Janeiro: Civilização Brasileira, 2010. v. 2: Brasil e América Latina.

Memória, opinião e cultura política. A Ordem dos Advogados do Brasil sob a Ditadura (1964-1974). In: REIS, D. A.; ROLLAND, D. (Orgs.). Modernidades alternativas. Rio de Janeiro: Fundação Getúlio Vargas, 2008, p. 57-96.

ROLLEMBERG, D.; QUADRAT, S. V. (Org.). “Introdução”. In: A construção social dos regimes autoritários: legitimidade, consenso e consentimento no Século XX. Rio de Janeiro: Civilização Brasileira, 2010. v. 2: Brasil e América Latina.

SCHUMPETER, J. Capitalismo, socialismo e democracia. Rio de Janeiro: Fundo de Cultura, 1961.

TROTSKY, L. A revolução Permanente. São Paulo: Expressão Popular, 2007.

A revolução traída. São Paulo: Sudermann, 2005.

VIANNA FILHO, O. Um pouco de pessedismo não faz mal a ninguém. Revista Civilização Brasileira, Caderno Especial de Teatro e Realidade Brasileira, a. 4, p. 69-78, 1968. 